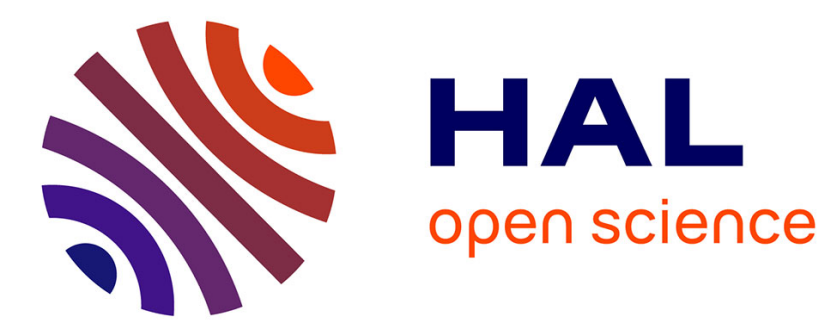

\title{
Life Cycle Assessment (LCA) Applied to the Design of an Innovative Drying Process for Sewage Sludge
}

C.A. Peregrina, Didier Lecomte, Patricia Arlabosse, V. Rudolph

\section{To cite this version:}

C.A. Peregrina, Didier Lecomte, Patricia Arlabosse, V. Rudolph. Life Cycle Assessment (LCA) Applied to the Design of an Innovative Drying Process for Sewage Sludge. Process Safety and Environmental Protection, 2006, 84 (4), pp.270-279. 10.1205/psep.05169 . hal-01165254

\section{HAL Id: hal-01165254 \\ https://imt-mines-albi.hal.science/hal-01165254}

Submitted on 18 Jun 2015

HAL is a multi-disciplinary open access archive for the deposit and dissemination of scientific research documents, whether they are published or not. The documents may come from teaching and research institutions in France or abroad, or from public or private research centers.
L'archive ouverte pluridisciplinaire HAL, est destinée au dépôt et à la diffusion de documents scientifiques de niveau recherche, publiés ou non, émanant des établissements d'enseignement et de recherche français ou étrangers, des laboratoires publics ou privés. 


\title{
Life cycle assessment (LCA) applied to the design of an innovative drying process for sewage sludge
}

\author{
Carlos A. Peregrina ${ }^{\mathrm{a}}$, Didier Lecomte ${ }^{\mathrm{a}}$, Patricia Arlabosse ${ }^{\mathrm{a}}$, Victor Rudolph ${ }^{\mathrm{b}}$ \\ a Laboratoire de Génie des Procédés des Solides Divisés (UMR 2392), \\ Ecole des Mines d'Albi Carmaux, Route de Teillet, 81013 Albi CT Cedex 09, France \\ ${ }^{b}$ Department of Chemical Engineering, \\ University of Queensland, St Lucia QLD 4072, Australia
}

\begin{abstract}
Most adverse environmental impacts result from design decisions made long before manufacturing or usage. In order to prevent this situation, several authors have proposed the application of life cycle assessment (LCA) at the very first phases of the design of a process, a product or a service. The study in this paper presents an innovative thermal drying process for sewage sludge called fry-drying, in which dewatered sludge is directly contacted in the dryer with hot recycled cooking oils (RCO) as the heat medium. Considering the practical difficulties for the disposal of these two wastes, fry-drying presents a potentially convenient method for their combined elimination by incineration of the final fry-dried sludge. An analytical comparison between a conventional drying process and the new proposed fry-drying process is reported, with reference to some environmental impact categories. The results of this study, applied at the earliest stages of the design of the process, assist evaluation of the feasibility of such system compared to a current disposal process for the drying and incineration of sewage sludge.
\end{abstract}

Keywords: LCA, frying, drying, sewage sludge, recycled cooking oil

Corresponding Author: Tel: 00.33(0)5.63.49.30.93; Fax: 00.33(0)5.63.49.32.43; e-mail: lecomte@enstimac.fr 


\section{Introduction}

After the food security scandals that occurred in the late 90's namely dioxin chicken and BSE (Bovine spongiform encephalopathy) contaminated meat, the reintroduction of biological wastes or by-products into the food chain has been eliminated. Recycled cooking oils (RCO) and sewage sludge are two by-products whose disposal requires over haul in this difficult context (d'Arcimoles, 2002, Boatella-Riera et al., 2000).

Along with the bans on sea dumping and landfilling, disposal of such wastes has focused on thermal treatment, preferably accompanied by energy recovery (Hall and Scrase, 1998). This may be accomplished by, as examples, RCO conversion to bio diesel (Ma and Hanna, 1999) or sewage sludge disposal to fuels by gasification and/or pyrolysis (Werther and Ogada, 1999). Nevertheless the most common thermal disposal method of both, by far, is by incineration or co-incineration with other wastes. However, because of its high moisture content, incineration of raw sewage sludge requires an intermediate thermal drying step (Werther and Ogada, 1999).

Fry-drying is an innovative technique for the thermal drying of sewage sludge. The process consists of immersing a mechanically dewatered sludge in a bath of hot RCO, maintained at a temperature some tens of degrees above the water boiling point (Peregrina et al., 2004).

Fry-drying avoids the plastic phase, which is one of the main contributors in the running costs for conventional sludge dryers (Lowe, 1995). Further, because of the oil impregnation, fry-dried sludge product has a higher calorific value, improving its fuel quality (Pires da Silva et al., 2003). Both the sludge and RCO may then be more easily co-disposed by incineration. 
Although there seems to be significant advantages of this new drying process for sludge, its development and implementation, are best informed by examination from a variety of perspectives (Hall and Scrase, 1998).

The feasibility of any new idea or a new process can be evaluated by comparing its performance with other equivalent or competing processes, usually assessed on a basis of technical, economical and environmental criteria (Cano-Ruiz and McRae, 1998).

The calculation of technical and economic performances can be made using extensive values (e.g. monetary values, energy contents) whereas the environmental impact needs a different approach. Environmental assessment uses a set of variables that are highly dependent on the assumptions made by the evaluators (Miettinen and Hamalainen, 1997), a subjective input, which raises difficulties when using any environmental assessment tool (Hertwich et al., 1997).

Life cycle assessment (LCA) is widely used to compare the relative environmental performance of competing processes, by analyzing the environmental impacts, which are generated by the processes within defined categories and boundaries. This highlights the advantages and disadvantages of the processes accentuating environmental weaknesses that require attention (Miettinen and Hamalainen, 1997).

LCA methodology, which is fully detailed in the series of norms ISO 14040-43, comprises four stages:

Goal and scope give the information regarding why the study is being carried out and what the comparative functional unit is. The evaluator must also present the boundaries and limits of the study.

Inventory involves the acquisition of quantitative data regarding the heat and mass streams, which according to the study's goal are considered the most important contributors of the related environmental impacts. 
Impact assessment evaluates the impacts generated by every material considered in the LCA inventory.

$\underline{\text { Interpretation }}$ aims to analyze, critically assess and draw conclusions from the information given by the LCA. An important issue is to identify the limitations that are inevitably associated with this method of analysis.

The success of the LCA method comes from the fact that it takes into account both global and local environmental impacts of all materials involved in a given process, from raw material extraction or compound synthesis to elimination of products and by-products. These impacts can be presented in the form of a common measuring unit, which depicts the global environmental performance of the process (Burgess and Brennan, 2001).

In spite of the strengths of the LCA technique for process assessment, the necessary use of assumptions remains a cause of criticism and disagreement in its practical application (Miettinen and Hamalainen, 1997). Among these assumptions are the definition of the boundaries of the process, the limitation of the number of species crossing the boundaries and the choice of the impact categories. Indeed, carrying out a complete inventory of the species involved in a process is logistically formidable and the evaluator usually has to limit studies to those species of major environmental concern. Practically, it is necessary to establish a hierarchy between different categories of impacts (global warming, acidification, abiotic depletion of resources, ...) and then make a choice. This is almost inevitable when input materials have a large variability in their composition or present a very large number of species which is the case with wastes, residues, contaminated soils or sludge (Chavez, 2004).

Environmental assessment of a process at the early stage of its feasibility or the broad range of possible options is an even more difficult work (Gasafi et al., 2004). The main constraints are the 
lack of data and the scale-up difficulties. However, although a number of simplifications have to be made, and in spite of the uncertainty, environmental assessment may be used - with necessary care - as a decision making tool to shift from R\&D to an industrial process (Hoffmann et al., 2001).

The aim of the present study is to examine some environmental impacts arising from the frydrying process as an intermediate step for the incineration of sewage sludge. The focus of the present paper is to assess the feasibility of a new sludge drying process by comparing its environmental performance to one standard indirect dryer. The assessment follows the general LCA methodology but with considerable simplifications and organized to make it applicable to the case under consideration. This may serve to provide additional insights regarding the use of fry-drying for the co-disposal of sewage sludge and recycled cooking oils.

\section{Preliminary definitions}

\section{Total solids and moisture content}

For the sewage sludge, total solids content $\chi_{\mathrm{TS}}$ is the mass ratio between the total solids $\mathrm{m}_{\mathrm{TS}}$ and the partially dried sludge $\mathrm{m}_{\mathrm{pds}}$,

$\chi_{\mathrm{TS}}=\frac{\mathrm{m}_{\mathrm{TS}}}{\mathrm{m}_{\mathrm{pds}}}$

Total solids mass is the matter that remains after drying at $105^{\circ} \mathrm{C}$ during 24 hours (Degremont, 1989). The mass removed $\mathrm{m}_{\mathrm{w}}$ is considered to be water. Thus, moisture content on wet basis can be defined as follows: 
$\chi_{\mathrm{W}}=\frac{\mathrm{m}_{\mathrm{W}}}{\mathrm{m}_{\mathrm{pds}}}=\frac{\mathrm{m}_{\mathrm{pdm}}-\mathrm{m}_{\mathrm{TS}}}{\mathrm{m}_{\mathrm{pds}}}$

The moisture content on dry basis $\delta_{\mathrm{w}}$ is given by:

$\delta_{\mathrm{W}}=\frac{\mathrm{m}_{\mathrm{w}}}{\mathrm{m}_{\mathrm{TS}}}=\frac{\mathrm{m}_{\mathrm{pdm}}-\mathrm{m}_{\mathrm{TS}}}{\mathrm{m}_{\mathrm{TS}}}$

\section{Oil content}

The degree of drying in given conditions depends on the drying time. Thus, at a time $t=i$, a sample of dry sludge will have a mass $\mathrm{m}_{\mathrm{pds}}^{\mathrm{t}=\mathrm{i}}$ comprising the mass of the moisture $\mathrm{m}_{\mathrm{w}}^{\mathrm{t}=\mathrm{i}}$ and the total solids mass $\mathrm{m}_{\mathrm{TS}}^{\mathrm{t}=\mathrm{i}}$. The latter is made up of the initial indigenous total solids $\mathrm{m}_{\mathrm{TS}}^{\mathrm{t}=0}$ and the mass of impregnated RCO $\mathrm{m}_{\mathrm{RCO}}^{\mathrm{t}=\mathrm{i}}$.

In a given test, $\mathrm{m}_{\mathrm{TS}}^{\mathrm{t}=0}$ is assumed to be constant since the sludge solids are insignificantly soluble in the frying oil and are not volatilized at the fry-drying temperatures. This permits the mass of impregnated oil $\mathrm{m}_{\mathrm{RCO}}^{\mathrm{t}=\mathrm{i}}$ to be obtained by mass difference as:

$\mathrm{m}_{\mathrm{RCO}}^{\mathrm{t}=\mathrm{i}}=\mathrm{m}_{\mathrm{pds}}^{\mathrm{t}=\mathrm{i}}-\mathrm{m}_{\mathrm{W}}^{\mathrm{t}=\mathrm{i}}-\mathrm{m}_{\mathrm{TS}}^{\mathrm{t}=0}$

Oil content can be expressed on wet or dry basis, given by ( 5 ) and ( 6 ) respectively:

$\chi_{\mathrm{RCO}}=\frac{\mathrm{m}_{\mathrm{RCO}}^{\mathrm{t}=\mathrm{i}}}{\mathrm{m}_{\mathrm{pds}}^{\mathrm{t}=\mathrm{i}}}$

$\delta_{\mathrm{RCO}}=\frac{\mathrm{m}_{\mathrm{RCO}}^{\mathrm{t}=\mathrm{i}}}{\mathrm{m}_{\mathrm{TS}}^{\mathrm{t}=\mathrm{i}}}$ 
or by reference to the indigenous total solids $\mathrm{m}_{\mathrm{TS}}^{\mathrm{t}=0}$, as follows:

$$
\xi_{\mathrm{RCO}}=\frac{\mathrm{m}_{\mathrm{F}}^{\mathrm{t}=\mathrm{i}}}{\mathrm{m}_{\mathrm{TS}}^{\mathrm{t}=0}}
$$

For the conventionally dried sludge the moisture content on dry basis $\delta_{\mathrm{w}}$ and moisture content referred to the indigenous total solids $\xi_{\mathrm{w}}$ are equivalent.

\section{Lower heating value of the partially dried sludge, $\mathbf{L H V}_{\text {pds }}$}

For any dry material composed of inert matter and organic matter, having a generic molecular formula of $\mathrm{C}_{\mathrm{n}} \mathrm{H}_{\mathrm{m}} \mathrm{O}_{\mathrm{p}} \mathrm{N}_{\mathrm{q}}$, the complete combustion reaction can be written as follows,

$\mathrm{C}_{\mathrm{n}} \mathrm{H}_{\mathrm{m}} \mathrm{O}_{\mathrm{p}} \mathrm{N}_{\mathrm{q}}+$ inert $+\left(\mathrm{n}+\frac{\mathrm{m}}{4}-\frac{\mathrm{p}}{2}\right) \mathrm{O}_{2} \rightarrow \mathrm{nCO}_{2}+\frac{\mathrm{m}}{2} \mathrm{H}_{2} \mathrm{O}+\frac{\mathrm{q}}{2} \mathrm{~N}_{2}+$ inert

The lower heating value of a dry fuel LHV is the heat released from a complete combustion reaction considering the water produced as vapor. Since partially dried sludge is a mixture of organic matter, inert matter and moisture, its lower calorific value $\mathrm{LHV}_{\mathrm{pds}}$ varies as:

$$
\mathrm{LHV}_{\mathrm{pds}}=\mathrm{LHV}_{\mathrm{TS}}^{\mathrm{t}=0} \cdot \chi_{\mathrm{TS}}-\Delta \mathrm{H}_{\mathrm{vapor}} \cdot\left(1-\chi_{\mathrm{TS}}\right)
$$

Where $\mathrm{LHV}_{\mathrm{TS}}^{\mathrm{t}=0}$ is the lower calorific value of the indigenous dry matter and $\Delta \mathrm{H}_{\text {evap }}$ is the latent heat of vaporization of water.

For fry dried sludge, $\mathrm{LHV}_{\mathrm{pds}}$ must take into account the fraction of solids corresponding to the impregnated oil $\delta_{\mathrm{RCO}}$ and the lower heating value of the oil $\mathrm{LHV}_{\mathrm{RCO}}$ :

$$
\mathrm{LHV}_{\mathrm{pds}}=\left[\mathrm{LHV}_{\mathrm{TS}}^{\mathrm{t}=0} \cdot\left(1-\delta_{\mathrm{RCO}}\right)+\mathrm{LHV}_{\mathrm{RCO}} \cdot \delta_{\mathrm{RCO}}\right] \cdot \chi_{\mathrm{TS}}-\Delta \mathrm{H}_{\mathrm{vapor}} \cdot\left(1-\chi_{\mathrm{TS}}\right)
$$


$\mathrm{LHV}_{\mathrm{TS}}^{\mathrm{t}=0}$ and $\mathrm{LHV}_{\mathrm{RCO}}$ were calculated from their Higher Heating Values HHV according to the equation ( 11 ), where HHV was measured using a self-contained "oxygen bomb" calorimeter (mod. C500, IKA Analysen Technik, Germany) following the method outlined in ASTM D3286 and the factor $\frac{18}{2} \cdot \delta_{\mathrm{H}}$ in equation (11), represents the mass fraction of water produced during combustion according to the stoichiometric proportion to the hydrogen content of the samples on dry basis.

$$
\mathrm{HHV}=\mathrm{LHV}+\frac{18}{2} \cdot \delta_{\mathrm{H}} \cdot \Delta \mathrm{H}_{\mathrm{vapor}}
$$

The hydrogen fraction $\delta_{\mathrm{H}}$ for the dried sludge and for the RCO were determined by ultimate analysis (C,H,N,S and $\mathrm{O}$ content determination) using a self-integrated and microprocessor controlled elemental analyzer (mod: NA 2100 Protein, CE Instruments, Italy) according to classic organic elemental analysis techniques (See results on Table 1).

After substituting the physical data into (9) and (10), the $\mathrm{LHV}_{\mathrm{pds}}$ may be calculated.

For the conventionally dried sludge:

$$
\mathrm{LHV}_{\mathrm{pds}}(\mathrm{MJ} / \mathrm{kg})=18.16 \cdot \chi_{\mathrm{TS}}-2.26
$$

For the fry-dried sludge:

$$
\mathrm{LHV}_{\mathrm{pds}}(\mathrm{MJ} / \mathrm{kg})=15.90 \cdot\left(1-\delta_{\mathrm{RCO}}\right) \cdot \chi_{\mathrm{TS}}+36.43 \cdot \delta_{\mathrm{RCO}} \cdot \chi_{\mathrm{TS}}-2.26\left(1-\chi_{\mathrm{TS}}\right)
$$

Equation ( 13 ) agreed with experimental data $\left(R^{2}=0.9554\right.$, see Figure 1 ) for a range of $\chi_{\text {TS }}$ between 0.35 and 0.98 which corresponds to a $\delta_{\mathrm{RCO}}$ ranging from 0.7 to 1.1 . 


\section{Auto-thermal combustion of the partially dried sludge}

Auto-thermal combustion requires a self-sustaining temperature inside the incinerator $\Delta \mathrm{T}_{\text {combustor }}$, to avoid a supply of any additional fuel (Werther and Ogada, 1999), where $\Delta \mathrm{T}_{\text {combustor }}$ is the temperature difference between the products (i.e. the blend of combustion species) and the reactants (i.e. the partially dried sludge) involved in the combustion.

$\Delta \mathrm{T}_{\text {combustor }}=\mathrm{T}_{\text {blend }}-\mathrm{T}_{\mathrm{pds}}$

Since industrial combustors operate at temperatures ranging between $650^{\circ} \mathrm{C}$ and $2000^{\circ} \mathrm{C}$ (Werther and Ogada, 1999), in this study it is considered that a $\Delta \mathrm{T}_{\text {combustor }}$ of $800 \mathrm{~K}$ is high enough to sustain an auto-thermal combustion.

The combustor temperature $\Delta \mathrm{T}_{\text {combustor }}$ may be calculated from the energy balance, most simply by assuming negligible heat losses and constant pressure. This is given by equation ( 15 ):

$\left(1+\psi_{\text {air }} \cdot \chi_{\mathrm{TS}}\right) \cdot \mathrm{Cp}_{\text {blend }} \cdot \Delta \mathrm{T}_{\text {combustor }}=\mathrm{LHV}_{\mathrm{pds}}$

$\mathrm{Cp}_{\text {blend }}$ is a weighted average specific heat of the species in the reactor over the temperature range, approximated by the combustion gases $\mathrm{Cp}_{\text {gas }}\left(1.2 \times 10^{-3} \mathrm{MJ} \cdot \mathrm{kg}^{-1} \cdot \mathrm{K}^{-1}\right)$, and the water evaporated $\left(\mathrm{Cp}_{\mathrm{H}_{2} \mathrm{O}}=2 \times 10^{-3} \mathrm{MJ} \cdot \mathrm{kg}^{-1} \cdot \mathrm{K}^{-1}\right)$. The mass fraction of the air with respect to the total solids $\psi_{\text {air }}$ of $10 \mathrm{~kg}$ air $\cdot \mathrm{kg}^{-1}$ total solids was assumed. Substitution into equation ( 15 ) gives:

$$
\Delta \mathrm{T}_{\text {combustor }}=\frac{\mathrm{LHV}_{\mathrm{pds}}}{\left(11.2 \cdot \chi_{\mathrm{TS}}-2\right) \cdot 10^{-3}}
$$

Assuming $\Delta \mathrm{T}_{\text {combustor }}=800 \mathrm{~K}$ for auto-thermal combustion, the minimum dryness of the sludge may be estimated. 


\section{LCA development}

\section{Goal and scope of the study}

\section{Goal}

The goal of this study was to compare the environmental performance of two case studies for the incineration and final disposal of 1 ton of indigenous dry matter contained in a mechanically dewatered sewage sludge having an initial total solids content equivalent to that of the WWTP of Albi (i.e. $\chi_{\mathrm{TS}}=0.19 \mathrm{~kg}$ of total soilds $\cdot \mathrm{kg}^{-1}$ of partially dried sludge).

\section{Environmental impact categories}

The environmental impact categories suggested by Poulsen and Hansen (2003) for sewage sludge treatment are:

Abiotic depletion of resources,

Climate change,

Acidification,

Eutrophication,

Ozone depletion,

Human health effects,

Ecotoxicity,

Land use and

Soil quality 
This study is limited only to those categories which could be calculated from the data collected and whose methodology is fully developed. Consequently ecotoxic and human health effects are left as externalities at this stage despite their obvious and critical importance. Since dried sludge is used here as fuel, soil quality impact is not relevant. Finally, land use and ozone depletion impacts are not expected to contribute significantly to the environmental outcome.

Consequently, the impact categories, which are considered in this study are the abiotic depletion of resources, climate change, acidification and eutrophication.

\section{Boundaries of the study}

Consistent with the goal of the assessment, this study focus mainly on the disposal of the sewage sludge and disregards alternatives for treatment and elimination for the recycled cooking oil. Consequently, the main difference between the two processes lies in the dryer itself. Figure 2 shows the boundaries of the considered scenario for disposal. The two case studies follow the same structure: successively a dryer, transportation of partially dried sludge, a combustor, transportation of combustion ashes and finally landfilling. Scenario 1 uses a conventional indirect paddle dryer (Chen et al., 2002) and scenario 2 uses a fry-dryer, which requires an additional feed material, namely, in this study, the RCO.

\section{Other assumptions of the study}

In order to assess only the effect of the dryer in the disposal system, the moisture content was limited simply to reach the auto-thermal point of the sludge. This meant that the sludge was dried just enough so that no supplementary fuel was required to maintain combustion.

Figure 3 and Figure 4 show the combustor adiabatic temperature change and the $\mathrm{LHV}_{\mathrm{pds}}$ as the sludge total solids content is varied for the conventional and fry-dried sludge respectively. To raise the temperature of the incinerator by $800 \mathrm{~K}$, sludge must be conventionally dried to a final total solids content of 0.42 , corresponding to $\mathrm{LHV}_{\mathrm{pds}}=5.37 \mathrm{MJ} \cdot \mathrm{kg}^{-1}$. For fry-dried sludge a solids 
content of 0.27 and $\mathrm{LHV}_{\mathrm{pds}}=4.11 \mathrm{MJ} \cdot \mathrm{kg}^{-1}$ provides the same result. This shows the effect of the impregnation of a high calorific value material, such the RCO, into the sludge as occurs during the fry-drying. The uptake of oil at different stages of drying are shown on Figure 5. The compositions of the two sludges partially dried to the auto-thermal point, for the two different drying methods are given on Table 2 .

\section{Inventory analysis}

Due to the early stages of development of the fry-dryer, most of the data were calculated or obtained experimentally following the methods described below. For the analysis we used a digested and dewatered sludge from the wastewater treatment plant (WWTP) of Albi city (France) and RCO from Sud Recuperation, a cooking oil recycler located in Muret (France). Proximate and ultimate analysis of these materials are presented in Table 1.

The laboratory results were scaled to a common basis of $1000 \mathrm{~kg}$ of sludge indigenous total solids.

\section{Inventory of drying}

The pollution emissions and energy consumption of an indirect dryer in the WWTP of VilleFranche-sur-Saone city in France (Lassus, 1999) served as a basis to compare the results obtained for the fry dryer. The sludge composition in the two cases is very comparable (See Table 1).

Energy consumption during drying was calculated as:

Thermal energy $=\frac{\text { Net heat load }}{\eta}$ 
A thermal efficiency $\eta=0.83$ has been reported for the indirect conventional dryer (Lassus, 1999). The same efficiency was assumed for the fry-dryer since it lies within the typical range of efficiencies for industrial fryers (Stier, 1996).

Net heat load for the conventional drying $\mathrm{NHL}_{\text {indirect dryer }}$ summarized the sensible and latent heat for the conventional drying (Lassus, 1999):

$\mathrm{NHL}_{\text {indirect dryer }}=\left(\mathrm{m}_{\mathrm{mds}} \cdot \mathrm{Cp}_{\mathrm{mds}} \cdot \Delta \mathrm{T}_{\mathrm{mds}}\right)+\left(\Delta \mathrm{H}_{\text {vapor }} \cdot \mathrm{m}_{\text {vapor }}\right)$

Where subscripts "mds" and "vapor" refer to the mechanically dewatered sludge and evaporated water respectively. Here, $\Delta \mathrm{H}_{\text {vapor }}=2258 \mathrm{~kJ} \cdot \mathrm{kg}^{-1} ; \Delta \mathrm{T}_{\mathrm{mds}}=80 \mathrm{~K}$; and $\mathrm{Cp}_{\mathrm{mds}}=3.65 \mathrm{~kJ} \cdot \mathrm{kg}^{-1} \cdot \mathrm{K}^{-1}$. The input total mass $\left(\mathrm{m}_{\mathrm{mds}}=5263 \mathrm{~kg}\right.$ ) is deduced from the study basis of $1000 \mathrm{~kg}$ of sludge indigenous total solids. The mass of evaporated water is:

$\mathrm{m}_{\text {vapor }}=\mathrm{m}_{\mathrm{mds}} \cdot \chi_{\mathrm{TS}}^{\mathrm{t}=0} \cdot\left(\xi_{\mathrm{W}}^{\mathrm{t}=0}-\xi_{\mathrm{W}}^{\text {auto-thermal }}\right)$

For the fry-dryer, sensible heat lost for the impregnated oil must be accounted for; this was included in equation ( 20 ) to obtain the $\mathrm{NHL}_{\text {fry-dryer }}$ :

$\mathrm{NHL}_{\text {fiy-dryer }}=\left(\mathrm{m}_{\mathrm{mds}} \cdot \mathrm{Cp}_{\mathrm{mds}} \cdot \Delta \mathrm{T}_{\mathrm{mds}}\right)+\left(\Delta \mathrm{H}_{\text {vapor }} \cdot \mathrm{m}_{\text {vapor }}\right)+\mathrm{m}_{\mathrm{TS}}^{\mathrm{t}=0} \cdot \xi_{\mathrm{RCO}}^{\text {auto-thermal }} \cdot \mathrm{Cp}_{\mathrm{RCO}} \cdot \Delta \mathrm{T}_{\mathrm{RCO}}$

Where $\mathrm{Cp}_{\mathrm{RCO}}=2.33 \mathrm{~kJ} \cdot \mathrm{kg}^{-1} \cdot \mathrm{K}^{-1} ; \Delta \mathrm{T}_{\mathrm{RCO}}=140 \mathrm{~K}$; and " $\xi_{\mathrm{RC} 0}^{\text {auto-thermal }}$ " is the oil content for the autothermal sludge referred to the indigenous total solids (See Figure 5).

Calculation of the thermal energy consumption during drying enables the estimation of the required amount of fuel and also the greenhouse emissions. Here, we assumed both dryers work with natural gas having an energy content of $47 \mathrm{MJ} \cdot \mathrm{kg}^{-1}$ and producing $2.8 \mathrm{~kg} \mathrm{CO} \cdot \mathrm{kg}^{-1}$ of natural gas (Poulsen and Hansen, 2003). Main input and output streams for the dryers are presented in Table 3. 
Emissions during drying were selected according to Lassus (1999). The emissions reported in that study for a conventional paddle dryer can be classified as condensed and non-condensed gases and were experimentally measured using analytical analysis. The same emissions were recovered from an experimental setup for the fry-drying of sewage sludge. The fry-drying experiment conditions followed the precedent of Peregrina et al. (2004) used to analyze the heat and mass transfer during the fry-drying of sewage sludge. However, in this study the experimental setup allows the capture of the exhaust gases to quantify the pollutant emissions (See Figure 6). Fry-drying takes place in a jacketed cylindrical reaction vessel with drain valve (mod. PRG-523502, Prism Research Glass, USA) half filled with $600 \mathrm{~mL}$ of RCO. The device is heated by a thermal oil heater (mod.MW-6, Julabo, Germany) to a frying oil temperature of $160^{\circ} \mathrm{C}$. The vessel is covered with a 6-neck lid (mod: PRG-7055, Prism Research Glass, USA). The central neck is used for the feeding and immersion of a $12 \mathrm{~g}$ sample of cylindrically shaped and dewatered sludge (See Figure 7). Another neck is used as the outlet for the exhaust vapors and is connected to an Allihn reflux type condenser (mod. UI-3500-10, Universal Instrument Company, USA). A third neck is plugged to a water column to stabilize the pressure changes occurring during the fry-drying. The other three remaining necks are closed for the whole experiment. A solution of 5\% vv ethylene glycol (CAS No.: 107-21-1, code: 5387, J.T. Baker, USA) circulates, at a controlled temperature of $0^{\circ} \mathrm{C}$, through a circuit linking the condenser and a refrigerating unit (mod. CC40, Huber, Germany). Condensed gases are recovered in a $250 \mathrm{~mL}$ flask (mod. C09458, Duran ${ }^{\circledR}$, USA).

The non-condensed gas is passed through a vacuum pump (mod. BR7530-60, Air Cadet ${ }^{\circledR}$, USA) and collected in a Tedlar ${ }^{\circledR}$ sealed gasbag (mod. C87918, cap. 37L, Fisher bioblock scientific, France). The flow of gases extraction is maintained at $8 \mathrm{~mL} \cdot \mathrm{s}^{-1}$ using a straight bore glass plug valve ( mod. PRG-255-03, Prism Research Glass, USA) connected before the gas-bag. Most of the exhaust vapors are recovered within the first 20 minutes. 
Phosphorus, nitrogen (test ISO 10695:2000), and chemical oxygen demand (COD) (test ISO 15705:2002) contained in the recovered condensate contribute directly to eutrophication impact whereas $\mathrm{SO}_{\mathrm{x}}, \mathrm{NO}_{\mathrm{x}}, \mathrm{CO}_{\mathrm{x}}$ and volatile organic compounds (VOC's) that may be present in the non-condensed gases are related to climate change. Non-condensed gases were quantified using a Fourier Transform Infrared Spectrometry (FTIR) as suggested by Salvador et al.(2004).

Concentrations of the recovered pollutants are given on Table 4. To calculate the total emissions from these measurements, it was assumed that the evaporated water forms the final condensate. An air flow of $1{\mathrm{~L} \cdot \mathrm{g}^{-1}}^{-1}$ evaporated water was the estimated in-leakage of air into the dryer.

\section{Combustion balances}

Energy consumption during combustion was zero because the partially dried sludge was assumed to be auto-thermal.

Combustion emissions were due only to the products of a complete combustion reaction of organic matter according to equation ( 8 ), of which only $\mathrm{CO}_{2}$ is relevant to climatic change. The small amounts of sulfur, present in the sewage sludge, was considered to be fully oxidized to $\mathrm{SO}_{2}$, an important contributor to acidification. Total combustion gas emissions were calculated according to stoichiometric proportions using the ultimate analysis of the partially dried sludge (See Table 2). The final solid residue of incineration, ash, which is finally disposed by landfill, is formed only by the initial mineral matter of the sludge and RCO. Total emissions during combustion are presented on Table 5.

Transportation balances 
Transportation emissions mainly depend on the size and/or volume of the product to be transported. For sewage sludge the use of mass equivalence factors to calculate the $\mathrm{CO}_{2}$ emissions and fuel consumptions is widely accepted (Poulsen and Hansen, 2003).

Energy consumption during transportation was calculated from the equivalence factor given by Poulsen and Hansen (2003) of $0.9 \mathrm{MJ} \cdot \mathrm{ton}^{-1} \mathrm{~km}^{-1}$ considering diesel as fuel. Distance between the wastewater plant and the incinerator and then to the landfill are assumed to be 10 and $15 \mathrm{~km}$ respectively.

Transportation emissions were derived from the fuel consumption using a factor $0.083 \mathrm{~kg} \mathrm{CO} \cdot \mathrm{MJ}^{-1}$ (Poulsen and Hansen, 2003).

\section{Impact assessment}

After the identification of the impacts and the quantification of the substances, the overall impact was evaluated according to the guidelines proposed by Heijungs et al. (1992), as follows:

$$
\mathrm{I}_{\mathrm{j}}=\sum_{\mathrm{e}=1}^{\mathrm{e}=\mathrm{m}} \sum_{\mathrm{x}=1}^{\mathrm{x}=\mathrm{n}} \mathrm{E}_{\mathrm{x}, \mathrm{e}} \times \mathrm{F}_{\mathrm{j}, \mathrm{x}, \mathrm{e}}
$$

Where:

$I_{j}$ is the score for the environmental impact category " $j$ ”;

$\mathrm{m}$ is the number compartments considered in the assessment;

$\mathrm{n}$ is the number of substances considered in the assessment;

$\mathrm{E}_{\mathrm{x}, \mathrm{e}}$ is the emission of the substance " $\mathrm{x}$ " released or consumed by the compartment " $\mathrm{e}$ " per functional unit; 
$F_{j, x, e}$ is the factor of characterization for the impact category " $j$ " for the substance " $x$ " consumed or emitted by the compartment " $\mathrm{e}$ ".

The characterization factors, $\mathrm{F}_{\mathrm{j}, \mathrm{x}, \mathrm{e}}$, vary according the impact category and the substances involved, as follows:

Abiotic depletion of resources summarizes the global energy balance of the fossil fuel energy resources consumed in the entire disposal system (Christiansen, 1991). It is accounted in MJ.

Climate change is characterized by the equivalent $\mathrm{kg}$ of $\mathrm{CO}_{2}$. The equivalence between the released amounts of green house gases, excluding water vapor, to those of $\mathrm{CO} 2$ are given by their corresponding global warming potential (GWP) considering a time horizon of 100 years (IPCC, 1996).

Eutrophication is the change in the level of nutrients in the ecosystem, and it is represented by equivalent $\mathrm{kg}$ of $\left(\mathrm{PO}_{4}\right)^{3-}$ (de Leeuw, 1993).

Acidification refers to equivalent $\mathrm{kg}$ of sulfur dioxide $\left(\mathrm{SO}_{2}\right)$ (de Leeuw, 1993).

Figure 8 shows the complete results, presented in equivalent units for each impact category, related to the functional unit of this assessment (i.e. $1000 \mathrm{~kg}$ of sludge indigenous total solids).

Figure 8 (a) shows that total energy requirements throughout the whole disposal system is dominated by the drying process. The much lower energy consumption for the scenario using the fry-dryer is noteworthy, i.e. $2854 \pm 30 \mathrm{MJ}$, compared to that using a conventional indirect dryer, i.e. $9713 \pm 30 \mathrm{MJ}$. In fact, fry-drying permits an enhancement of the sludge calorific content $\mathrm{LHV}_{\mathrm{pds}}$, both by removing water and adding oil. Hence, a lower amount of water is needed to be evaporated in order to reach the auto-thermal condition. This reduces the energy requirements and therefore the abiotic depletion impact for the fry-dryer scenario. Although mass reduction for the fry-dryer is slight compared to conventional case, energy saving achieved by the fry-dryer overwhelms the small additional energy required during the transport. 
In Figure 8(b) climate change related emissions are summarized in the form of $\mathrm{CO}_{2}$ equivalent units. The two biggest contributions are, from one side, the incineration, which is higher for the fry-drying case due to the presence of the impregnated oil, and from the other, the consumption of fuels during the drying, which is higher for the conventional case since it involves a greater water evaporation.

Acidification contribution is presented in Figure 8(c) and is due to the combustion emissions in terms of equivalent $\mathrm{kg}$ of $\mathrm{SO}_{2}$. Considering that the oil does not contain any additional sulfur and within the accuracy of the measurements, the effect of both systems is effectively equivalent.

Finally, Figure 8(d) presents the eutrophication contributions due to the condensate collection. It is important to note that the recovered fry-dryer condensates had a very high COD, i.e. $6420 \mathrm{mg}$ $\mathrm{O}_{2} \cdot \mathrm{L}^{-1}$ as shown on Table 4 , which is 6 to 12 times the maximum accepted value in a WWTP (Lassus and Toupart, 1998). However, this can be put into perspective if is considered that condensate can be mixed, and therefore diluted, into the input wastewater stream. Actually, the amounts of eutrophication pollutants for the two scenarios are very small in terms of mass involved (less than $0.5 \%$ of that concerning acidification and less than $0.0005 \%$ of climate change, see Figure 8). Finally, a positive outcome for fry-drying is that nitrogen and phosphorus compounds were retained in the partially dried sludge during the fry-drying, avoiding their concentration in the exhausted vapors.

Figure 9 gives another representation of the inventory results. There, all the individual contributions were classified by impact categories and normalized with respect to the most important contributor. In order to make the decision-making as transparent as possible, we do not use weighting factors to aggregate these data. Relativities between the categories are further discussed in the LCA interpretation section. 


\section{LCA interpretation}

Figure 9 indicates the relative merits of each process compared with the other but does not attempt to weight the categories themselves. Within these 4 categories fry-drying is a better environmental option in terms of abiotic depletion of resources (Figure 9a). Within the accuracy of the data the acidification impacts are equivalent (Figure 9c). Fry-drying is worse in the two remaining categories namely climatic change and eutrophication (Figure 9b and d). Based on the study inventory, it is evident that in simple mass terms the eutrophication is not very important compared with the other categories. Thus, the study conclusions are directed to the abiotic depletion of resources and climatic change categories.

The most important environmental and economic issue of fry-drying is in the abiotic depletion of resources. Simultaneous impregnation and drying of sludge using a low value product with a high energy content, such as RCO, enables the partially dried sludge to reach its auto-thermal point without needing to evaporate big amounts of water and consequently consuming less fossil fuels than conventional dryers. This environmental advantage, added to the technical issues of the frydrying of sewage sludge (Peregrina et al., 2004), promotes its application in the disposal of sludge by incineration.

This study enables decision makers to examine the climate change impact results in perspective. In fact, emissions due to the fraction of RCO contained in the fry-dried during combustion would have been similar in any other RCO disposal route. Indeed, in accordance with the current European legislative requirements (Boatella-Riera et al., 2000), RCO is eliminated mainly by incineration.

Since the aim of this study was limited to the fry-drying as an intermediate step in the disposal of sewage sludge, issues associated with the disposal of RCO were not included. However, a LCA that focuses on the co-disposal of RCO and sewage sludge, including the environmental impacts 
related to the alternative disposal of RCO, would give a more inclusive idea of the environmental advantages of fry-drying.

An additional consideration, which could be a major concern requiring further analysis, is that chlorine content of RCO may not be negligible and can range in a year from 5 to $1020 \mathrm{mg}^{\cdot \mathrm{kg}^{-1}}$ of RCO. It is known that in the presence of organic matter and high temperature (e.g. 500 to 800 ${ }^{\circ} \mathrm{C}$ ) chlorine may promote the formation of other toxics like dioxins and furans (McKay, 2002). Although ecotoxic impacts have been considered as an externality in this comparison, chlorine content control in the recycled cooking oil or in any other alternative fry-drying oils should be a priority consideration regarding environmental performance of such operation.

\section{Conclusions}

LCA has been applied in the first stages of the design of a new drying process for sludge integrated in the co-disposal of sewage sludge and RCO. The study compares aspects of environmental performance with conventional disposal of sludge by incineration. Several assumptions were required in order to compare the data obtained from a lab scale fry-dryer to full-scale indirect sewage sludge dryer.

Four relevant impact categories were selected to assess the environmental profile of the operation - abiotic depletion of resources, climate change, eutrophication and acidification. Although toxic impacts are an important determinant of environmental performance, they were considered as externalities of our study because the lack of reliable data and their insufficiently developed assessment methodology.

Among the selected impact categories, fry-drying has shown a good performance in abiotic depletion of resources, i.e. the use of fossil fuels, and maybe in climate change if we would consider the co-disposal of RCO. The LCA inventory showed the small importance of 
eutrophication compared with the others impact categories. Information related to acidification impacts was not accurate enough to distinguish the two disposal methods.

An economic assessment is a necessary complement for this study in order to determine the feasibility of fry-drying as an intermediate step in the disposal of sludge by incineration. 


\section{Nomenclature}

\section{Roman Letters}

$\begin{array}{lll}\mathrm{Cp} & \text { Specific heat } & \mathrm{J} \cdot \mathrm{kg}^{-1} \cdot \mathrm{K}^{-1} \\ \mathrm{HHV} & \text { Higher heating value } & \mathrm{J} \cdot \mathrm{kg}^{-1} \\ \Delta \mathrm{H}_{\text {evap }} & \text { Latent heat of vaporization } & \mathrm{J} \cdot \mathrm{kg}^{-1} \\ \mathrm{LHV} & \text { Lower heating value } & \mathrm{J} \cdot \mathrm{kg}^{-1} \\ \mathrm{~m} & \text { Mass } & \mathrm{kg} \\ \mathrm{NHL} & \text { Net heat load } & \mathrm{J} \\ \Delta \mathrm{T} & \text { Temperature elevation } & \mathrm{K}\end{array}$

\section{Greek letters}

$\delta$

$\eta$

$\xi$

$\chi$

$\psi$

Mass fraction on dry basis

Thermal efficiency of the dryer

Mass fraction referred to the indigenous total $\mathrm{kg} \mathrm{kg}^{-1}$

solids

Mass fraction on wet basis

Ratio of combustion air with respect to the $\mathrm{kg} \cdot \mathrm{kg}^{-1}$

total solids

\section{Subscripts/superscripts}

air

auto-thermal

blend

combustor

fry-dryer

gas

$\mathrm{H}$
Combustion air

Auto-thermal composition

Blend of combustion gases

Combustor chamber

Fry-drying process

Combustion gases except water vapor

Hydrogen $\mathrm{kg} \cdot \mathrm{kg}^{-1}$

$\mathrm{J} \cdot \mathrm{J}^{-1}$

$\mathrm{kg} \cdot \mathrm{kg}^{-1}$ 
indirect dryer

mds

pds

RCO

TS

$\mathrm{t}=0$

$\mathrm{t}=\mathrm{i}$

$\mathrm{H}_{2} \mathrm{O}$

W

vapor
Conventional indirect drying process

Mechanically dewatered sludge

Partially dried sludge

Recycled cooking oils

Total solids

Initial conditions

Conditions at drying time " $\mathrm{i}$ ”

Water vapor produced during combustion

Moisture

Evaporated water 


\section{Table titles}

Table 1 - Proximate and ultimate analysis of the RCO and the sewage sludge from the WWTP of Albi and of Ville-Franche-sur-Saone (Lassus, 1999)

Table 2 - Calculated composition for the auto-thermal partially dried sludge

Table 3 -Input and output mass streams in the two dryers

Table 4 -Pollutant concentrations of the selected emissions for the two dryers of sewage sludge

Table 5 - Pollutant emissions during the incineration of the partially dried sludge 
Table 1. "Life cycle assessment (LCA) applied to the design of an innovative drying process for sewage sludge" by Peregrina, Lecomte, Arlabosse and Rudolph.

\begin{tabular}{|c|c|c|c|}
\hline Component & $\begin{array}{c}\text { Recycled Cooking } \\
\text { Oils* }\end{array}$ & $\begin{array}{l}\text { Sewage sludge } \\
\text { from WWTP in } \\
\text { Albi* }\end{array}$ & $\begin{array}{l}\text { Sewage sludge from } \\
\text { WWTP in Ville- } \\
\text { Franche-sur-Saone } \\
\text { (Lassus, 1999) }\end{array}$ \\
\hline $\begin{array}{c}\text { Total Solids } \\
(\%)\end{array}$ & $97 \pm 3$ & $19 \pm 3$ & 26.5 \\
\hline $\begin{array}{c}\text { Mineral } \\
\text { matter }(\% \mathrm{TS})\end{array}$ & $0.6 \pm 0.6$ & $33 \pm 3$ & 31 \\
\hline $\begin{array}{c}\text { Organic } \\
\text { matter (\%TS) }\end{array}$ & $99.4 \pm 0.6$ & $67 \pm 3$ & 69 \\
\hline [C] $(\% \mathrm{TS})$ & $77.4 \pm 0.4$ & $36.4 \pm 3$ & 40.5 \\
\hline$[\mathbf{H}](\% \mathrm{TS})$ & $12.3 \pm 0.3$ & $5.5 \pm 0.2$ & 5.7 \\
\hline [O] $(\% \mathrm{TS})$ & $10.2 \pm 0.7$ & $18.8 \pm 1.5$ & 18.7 \\
\hline$[\mathbf{N}](\% \mathrm{TS})$ & $0.2 \pm 0.2$ & $5.7 \pm 0.2$ & 3.4 \\
\hline [S] $(\% \mathrm{TS})$ & $<0.01$ & $1.0 \pm 0.1$ & 0.7 \\
\hline
\end{tabular}


Table 2. "Life cycle assessment (LCA) applied to the design of an innovative drying process for sewage sludge" by Peregrina, Lecomte, Arlabosse and Rudolph.

\begin{tabular}{|c|c|c|}
\hline Component & Fry-drying & $\begin{array}{l}\text { Conventional } \\
\text { drying }\end{array}$ \\
\hline $\begin{array}{c}\text { Total Solids } \\
(\%)\end{array}$ & 26.6 & 42.0 \\
\hline $\begin{array}{c}\text { Mineral } \\
\text { matter }(\% \mathrm{TS})\end{array}$ & $24.6 \pm 3.6$ & $33 \pm 3$ \\
\hline $\begin{array}{c}\text { Organic } \\
\text { matter }(\% \mathrm{TS})\end{array}$ & $75.4 \pm 3.6$ & $67 \pm 3$ \\
\hline [C] (\%TS) & $47.0 \pm 3.4$ & $36.4 \pm 3$ \\
\hline$[\mathbf{H}](\% \mathrm{TS})$ & $7.3 \pm 0.5$ & $5.5 \pm 0.2$ \\
\hline [O] (\%TS) & $16.6 \pm 2.2$ & $18.8 \pm 1.5$ \\
\hline$[\mathbf{N}](\% \mathrm{TS})$ & $4.3 \pm 0.4$ & $5.7 \pm 0.2$ \\
\hline [S] (\%TS) & $0.7 \pm 0.1$ & $1.0 \pm 0.1$ \\
\hline
\end{tabular}


Table 3. "Life cycle assessment (LCA) applied to the design of an innovative drying process for sewage sludge" by Peregrina, Lecomte, Arlabosse and Rudolph.

\begin{tabular}{|c|c|c|}
\hline Stream & Fry-drying & Conventional drying \\
\hline Total solids $(\mathrm{kg})$ & $1000^{*}$ & $1000^{*}$ \\
\hline $\begin{array}{c}\text { Mechanically Dewatered } \\
\text { sludge }(\mathrm{kg})\end{array}$ & $5263^{*}$ & $5263^{*}$ \\
\hline Evaporated water (kg) & 560 & 2880 \\
\hline Impregnated RCO $(\mathrm{kg})$ & 350 & 0 \\
\hline $\begin{array}{l}\text { Auto-thermal partially } \\
\text { dried sludge }(\mathrm{kg})\end{array}$ & 5053 & 2383 \\
\hline Natural Gas (kg) & 75 & 206 \\
\hline Fuel $\mathrm{CO}_{2}$ emissions $(\mathrm{kg})$ & 209 & 577 \\
\hline
\end{tabular}


Table 4. "Life cycle assessment (LCA) applied to the design of an innovative drying process for sewage sludge" by Peregrina, Lecomte, Arlabosse and Rudolph.

\begin{tabular}{|c|c|c|c|}
\hline Stream & Pollutant & Fry-drying & Conventional drying \\
\hline \multirow{3}{*}{ Condensates } & {$[\mathrm{P}](\mathrm{mg} / \mathrm{L})$} & $<0.1$ & $0.2 \pm 0.1$ \\
\hline & {$[\mathbf{N}](\mathrm{mg} / \mathrm{L})$} & $0.1 \pm 0.1$ & $32.5 \pm 0.1$ \\
\hline & [COD] $\left(\mathrm{mg} \mathrm{O}_{2} / \mathrm{L}\right)$ & $228 \pm 1$ & $6420 \pm 1$ \\
\hline \multirow{5}{*}{$\begin{array}{c}\text { Non } \\
\text { Condensates }\end{array}$} & [Total VOC's] (ppmv) & $256 \pm 5 \%$ & $448 \pm 5 \%$ \\
\hline & {$\left[\mathbf{C H}_{4}\right]$ (ppmv) } & $7 \pm 5 \%$ & $11 \pm 5 \%$ \\
\hline & {$\left[\mathbf{S O}_{\mathbf{x}}\right](\mathrm{ppmv})$} & $<10$ & $<10$ \\
\hline & {$\left[\mathbf{N O}_{\mathbf{x}}\right]$ (ppmv) } & $<10$ & $<10$ \\
\hline & {$\left[\mathbf{C O}_{\mathbf{x}}\right](\mathrm{ppmv})$} & $<10$ & $<10$ \\
\hline
\end{tabular}


Table 5. "Life cycle assessment (LCA) applied to the design of an innovative drying process for sewage sludge" by Peregrina, Lecomte, Arlabosse and Rudolph.

\begin{tabular}{c|cc}
\hline Emissions & Fry-drying & Conventional drying \\
\hline $\mathbf{C O}_{2}(\mathrm{~kg})$ & $2330 \pm 169$ & $1336 \pm 110$ \\
$\mathbf{S O}_{2}(\mathrm{~kg})$ & $19 \pm 2$ & $20 \pm 2$ \\
Ash $(\mathrm{kg})$ & $332 \pm 49$ & $330 \pm 30$
\end{tabular}




\section{Figure captions}

Figure 1 - Correlation between LHV and $\chi_{\mathrm{TS}}$ for fry-dried sludge

Figure 2 - Boundaries of the assessment

Figure 3 - Adiabatic temperature change and lower heating value versus moisture level for the conventionally dried sludge from the WWTP of Albi

Figure 4-Adiabatic temperature change and lower heating value versus moisture level for the fry-dried sludge from the WWTP of Albi

Figure 5 - Oil uptake and drying curves for the fry-dryer

Figure 6-Experimental set up to recover the fry- drying exhaust vapours

Figure 7 - Immersion of the sludge sample into the reactor

Figure 8 - Inventory of streams considered in the assessment

Figure 9 - Normalized impact categories with respect to the most important contributor 
Figure 1 "Life cycle assessment (LCA) applied to the design of an innovative drying process for sewage sludge" by Peregrina, Lecomte, Arlabosse and Rudolph.

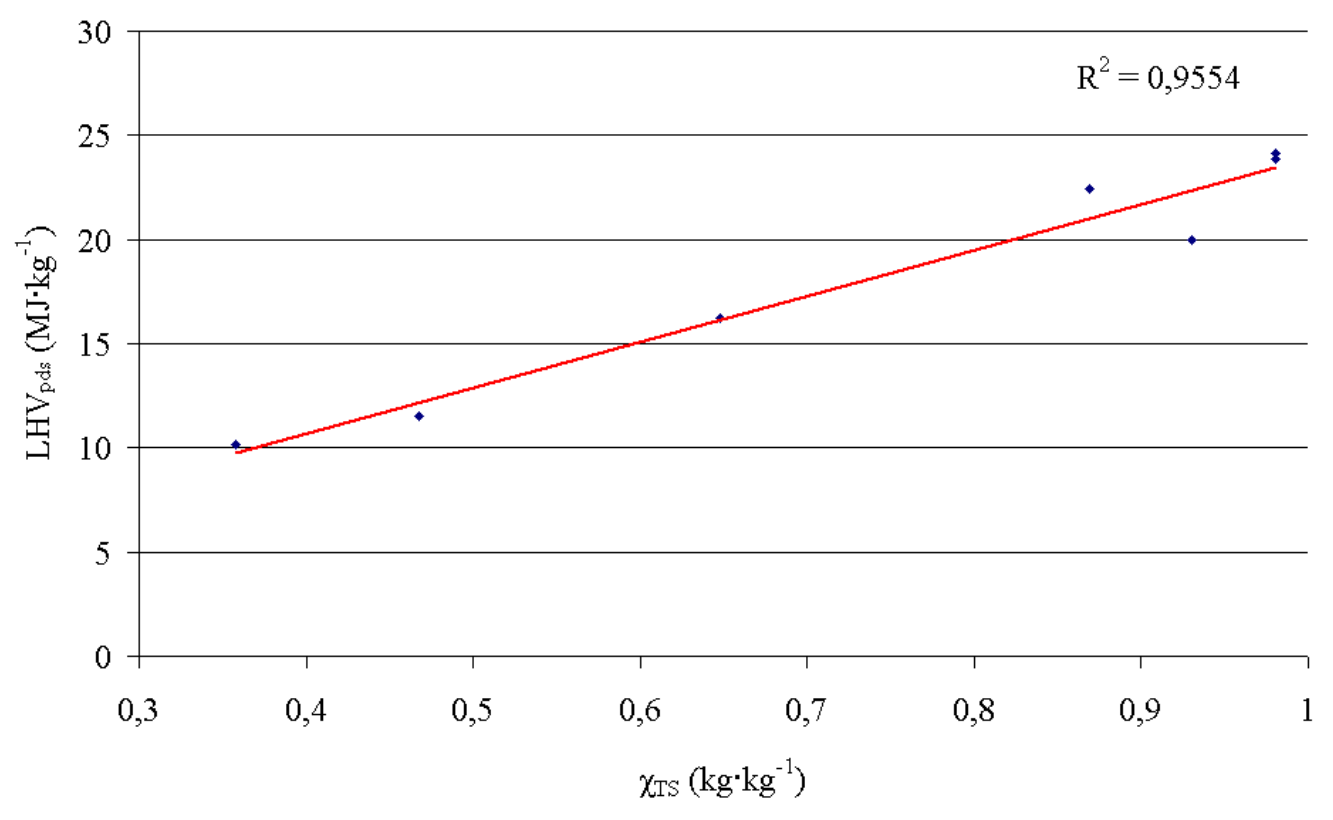


Figure 2 "Life cycle assessment (LCA) applied to the design of an innovative drying process for sewage sludge" by Peregrina, Lecomte, Arlabosse and Rudolph.

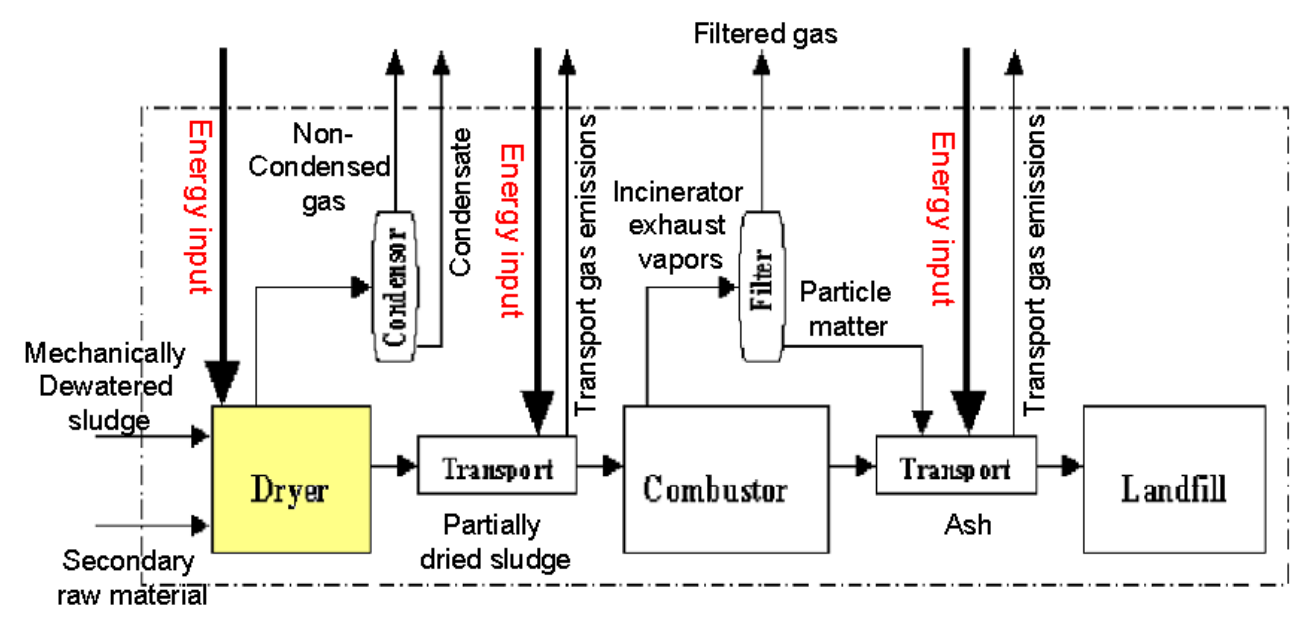


Figure 3 "Life cycle assessment (LCA) applied to the design of an innovative drying process for sewage sludge" by Peregrina, Lecomte, Arlabosse and Rudolph.

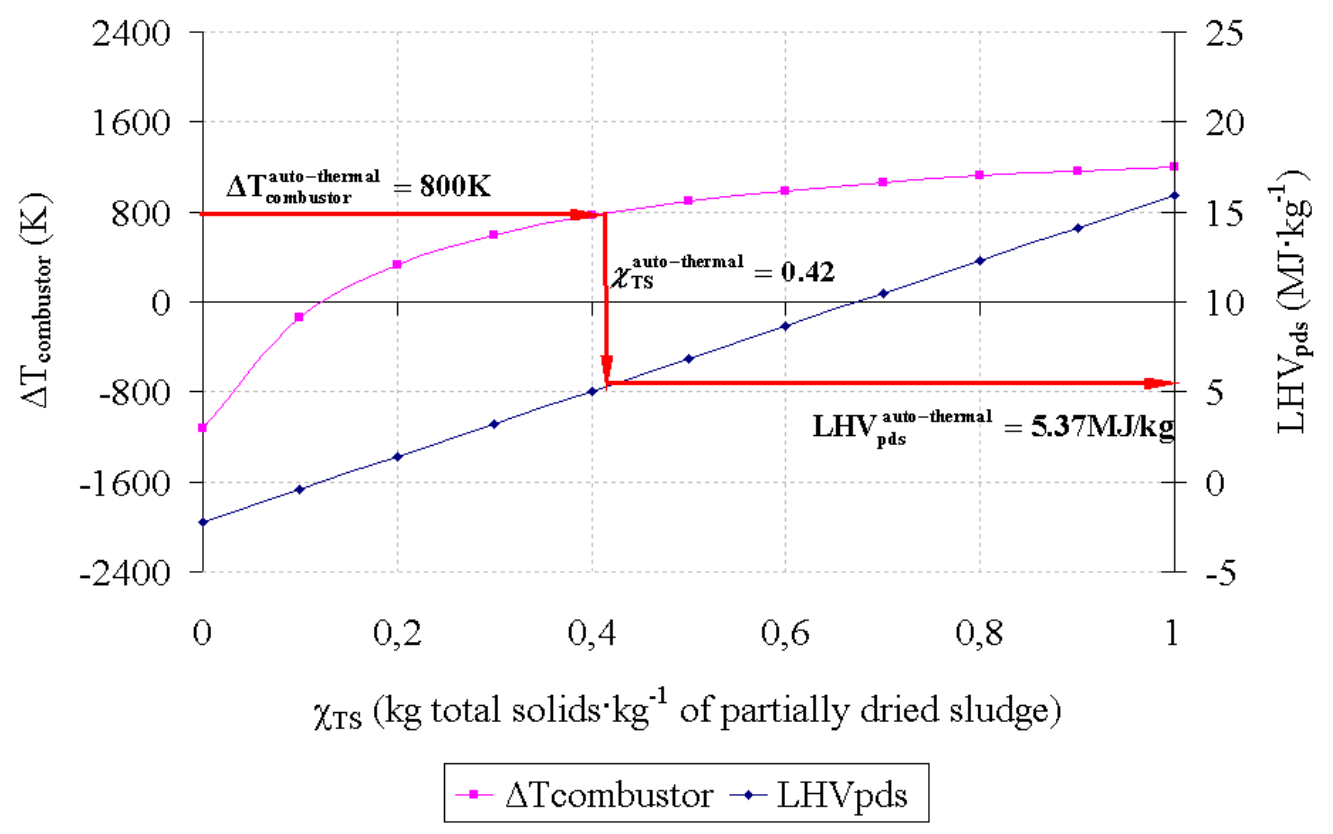


Figure 4 "Life cycle assessment (LCA) applied to the design of an innovative drying process for sewage sludge" by Peregrina, Lecomte, Arlabosse and Rudolph.

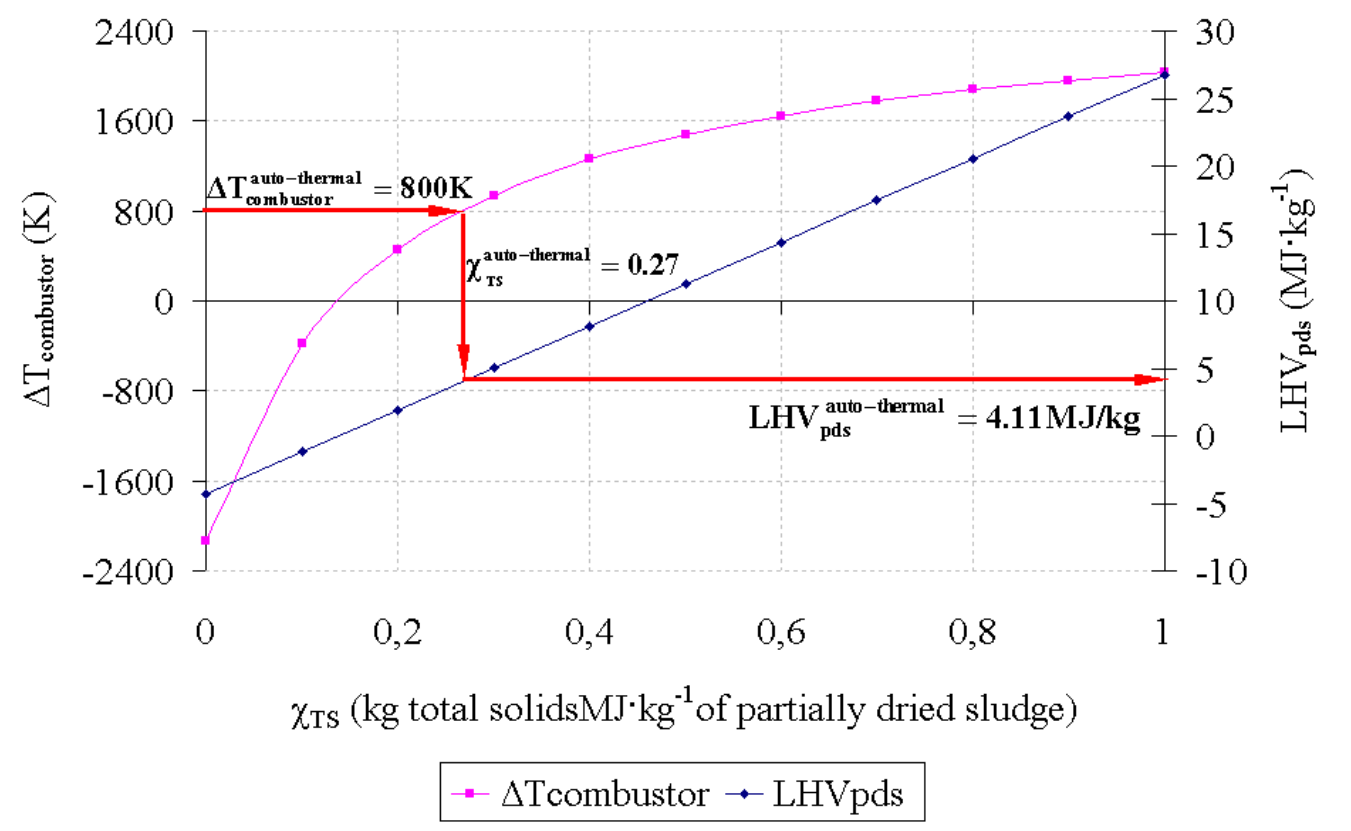


Figure 5 "Life cycle assessment (LCA) applied to the design of an innovative drying process for sewage sludge" by Peregrina, Lecomte, Arlabosse and Rudolph.

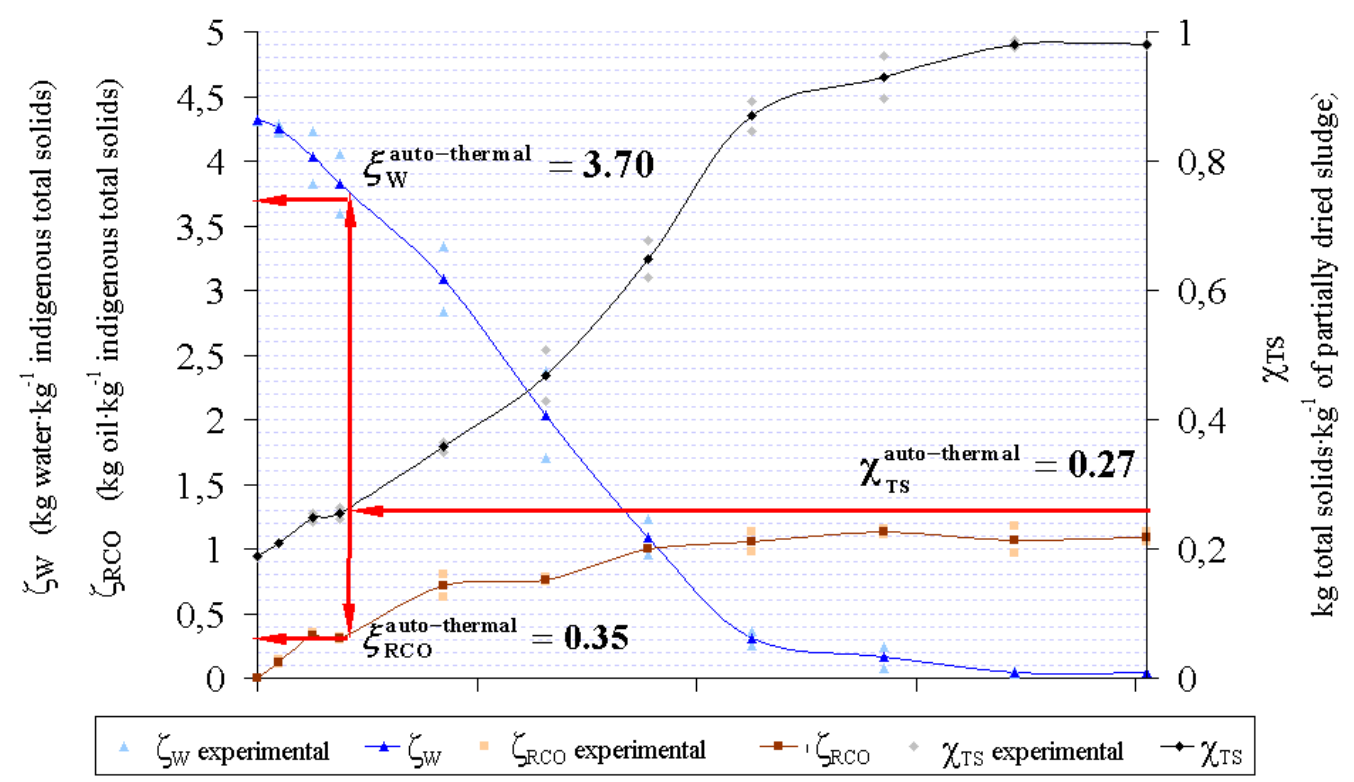


Figure 6 "Life cycle assessment (LCA) applied to the design of an innovative drying process for sewage sludge" by Peregrina, Lecomte, Arlabosse and Rudolph.

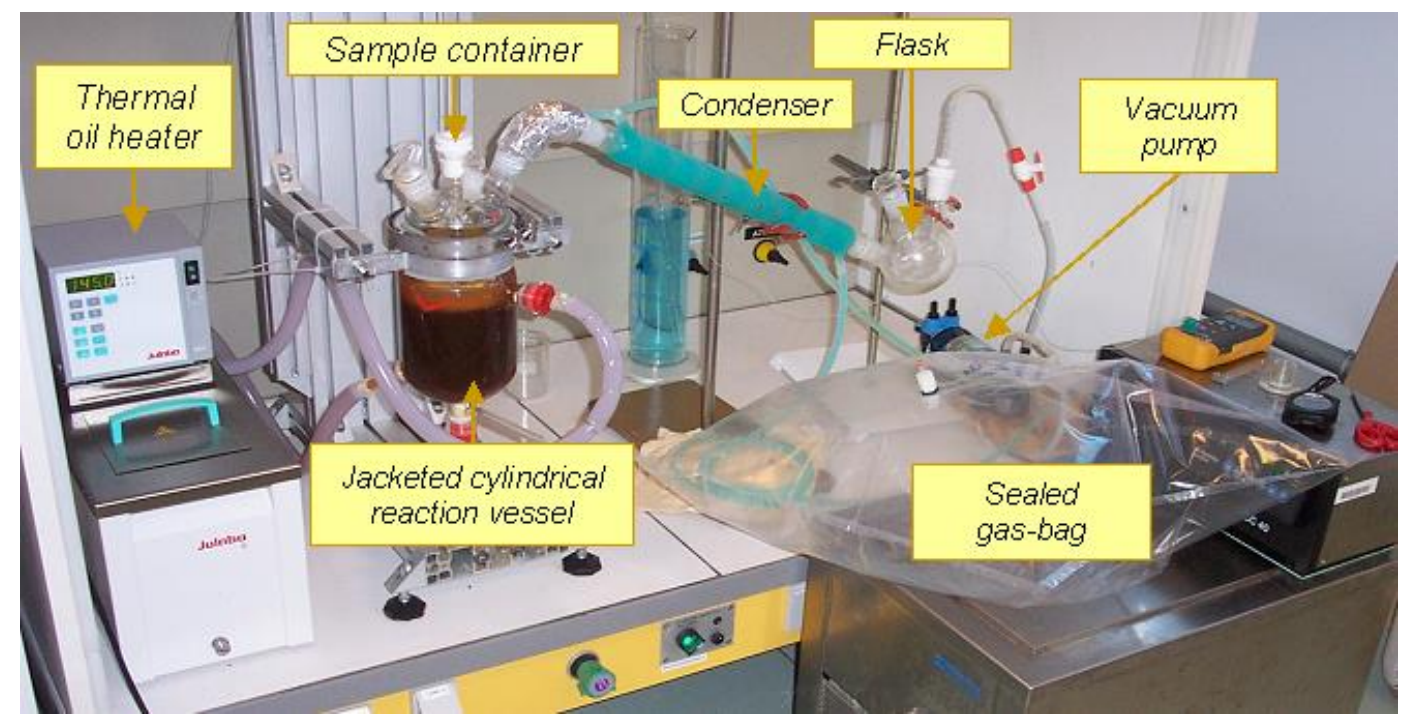


Figure 7 "Life cycle assessment (LCA) applied to the design of an innovative drying process for sewage sludge" by Peregrina, Lecomte, Arlabosse and Rudolph.

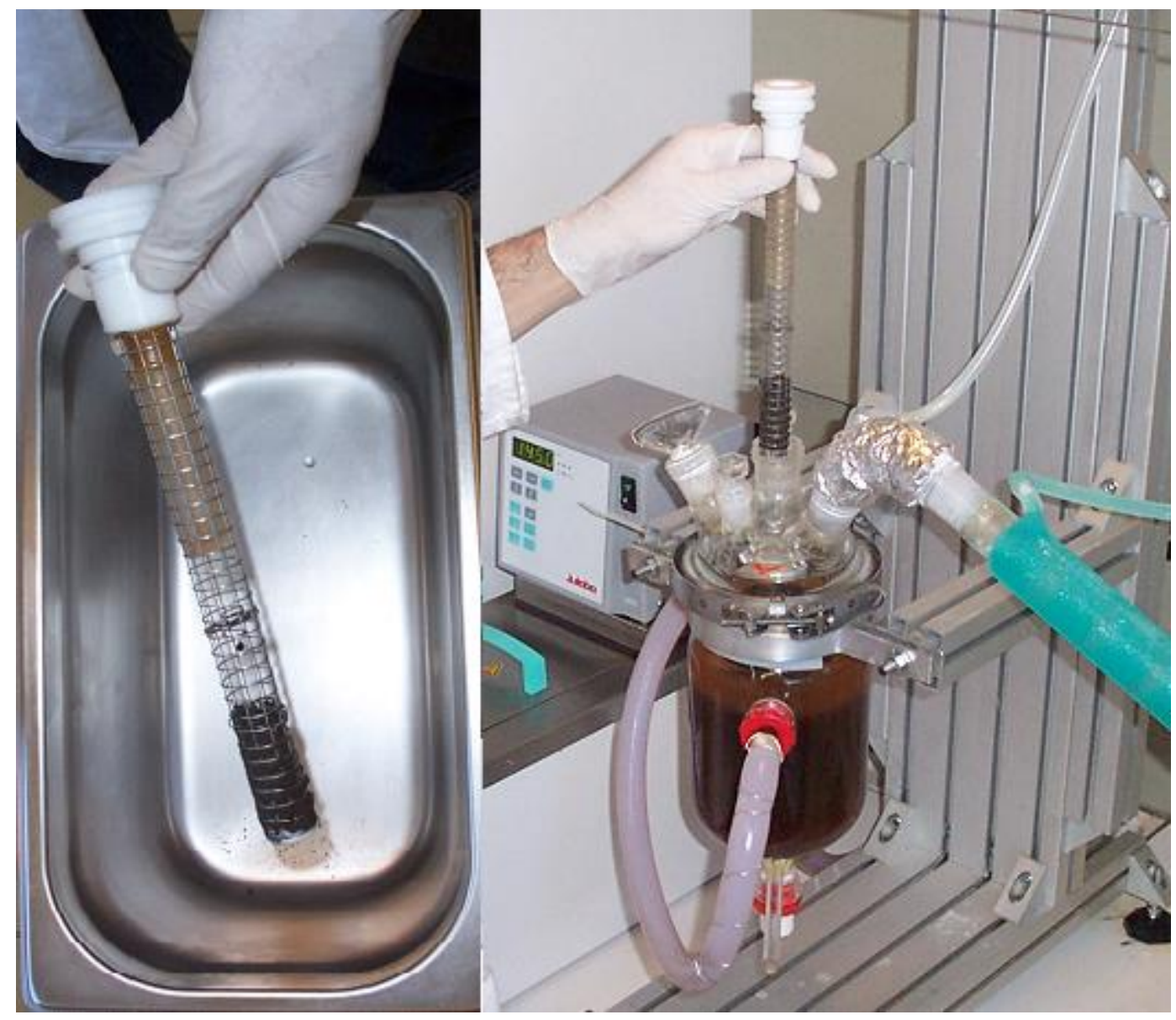


Figure 8. "Life cycle assessment (LCA) applied to the design of an innovative drying process for sewage sludge" by Peregrina, Lecomte, Arlabosse and Rudolph.

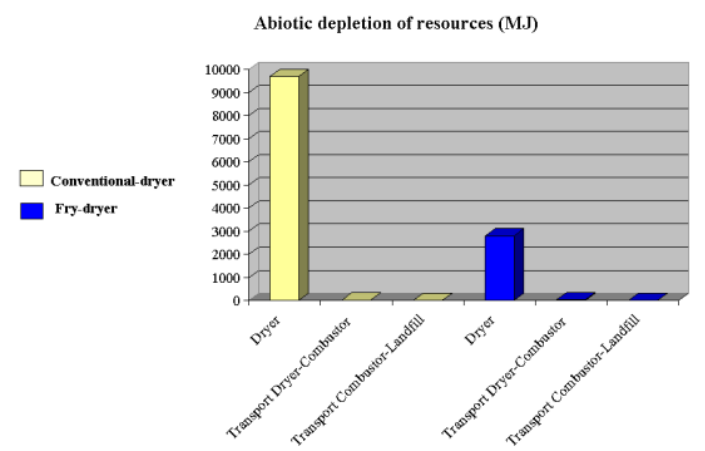

(a)

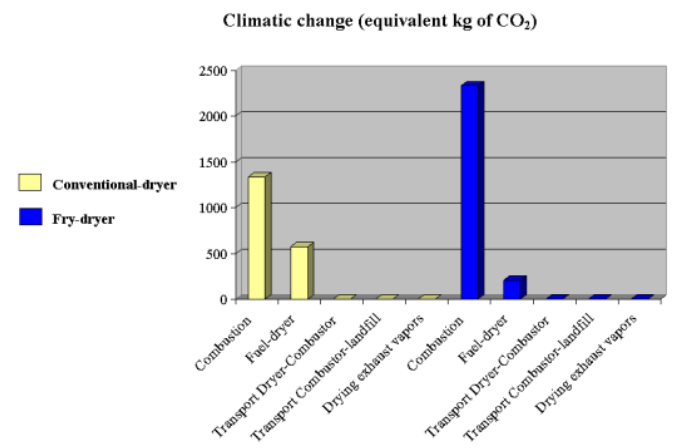

(b)

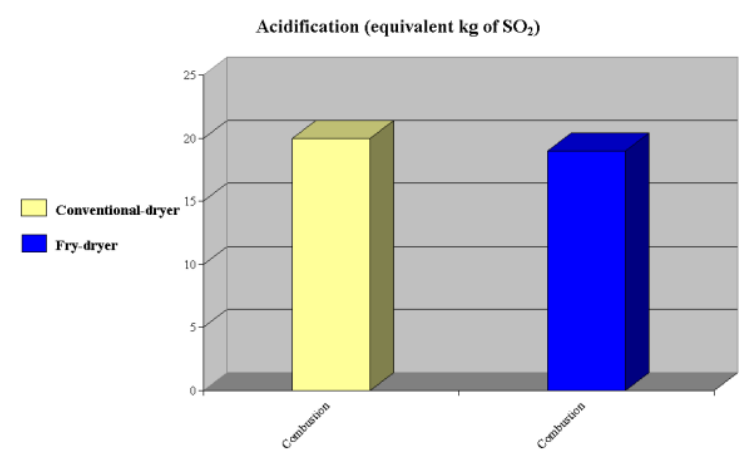

(c)

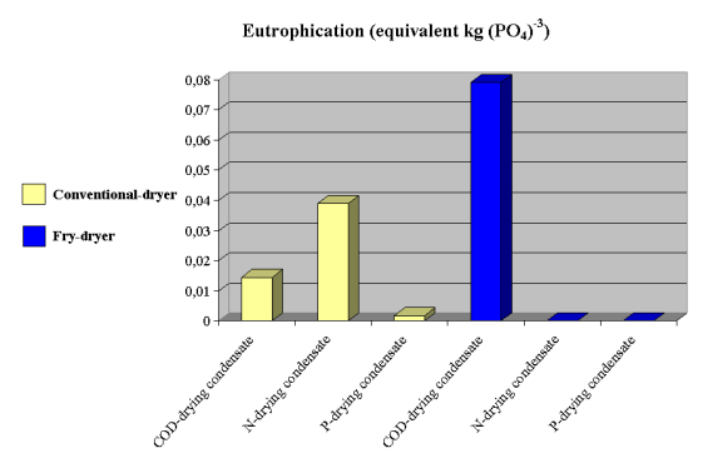

(d) 
Figure 9. "Life cycle assessment (LCA) applied to the design of an innovative drying process for sewage sludge" by Peregrina, Lecomte, Arlabosse and Rudolph.

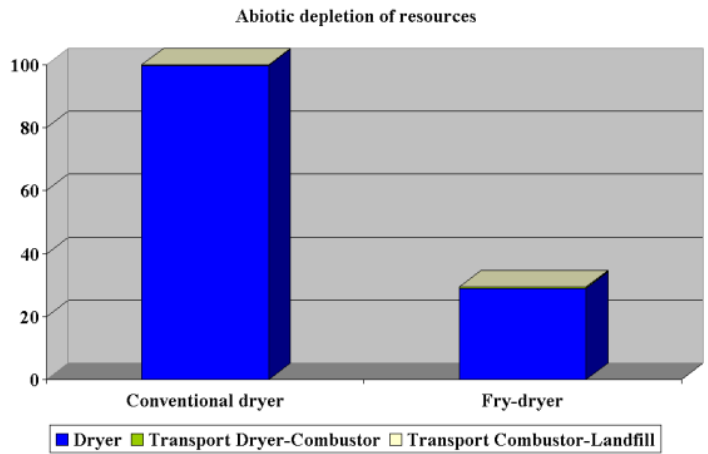

(a)

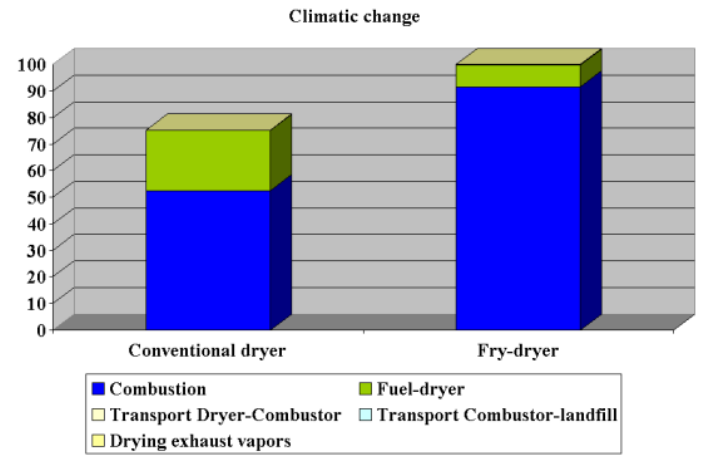

(b)

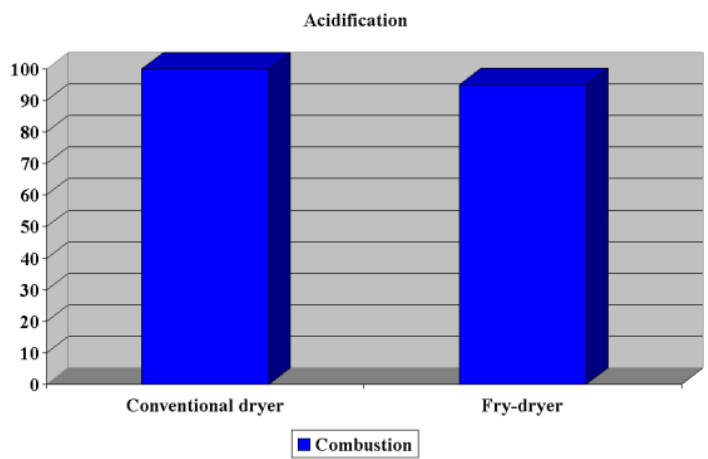

(c)

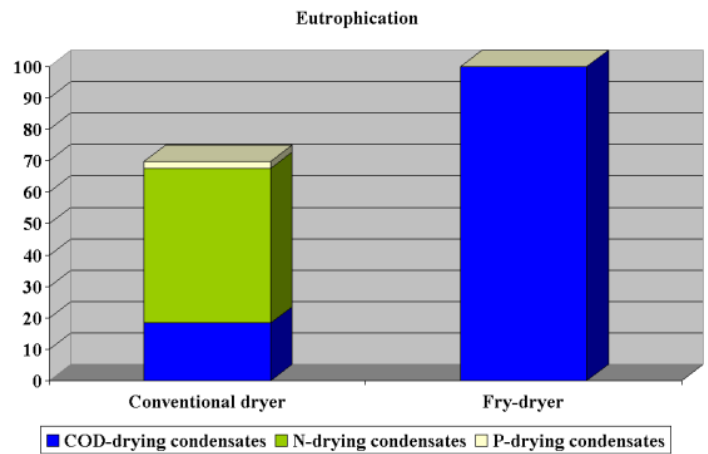

(d) 


\section{Acknowledgements}

Authors acknowledge financial support from the French Agency for Environment and Energy Management (ADEME), the Midi Pyrénées Region (France), and the Mexican National Council for Science and Technology (CONACy'T).

\section{References}

Boatella-Riera, J., Codony, R., Rafecas, M. and Guardioal, F., (2000), Recycled cooking oils: Assessments of risk for public health, European Parliament, (Luxembourg), pp. 1-100.

Burgess, A. A. and Brennan, D. J. (2001). Application of life cycle assessment to chemical processes. Chemical Engineering Science, 56(8): 2589-2604.

Cano-Ruiz, J. A. and McRae, G. J. (1998). Environmentally conscious chemical process design. Annual Review of Energy and the Environment, 23(1): 499-536.

Chavez, S. (2004) PhD thesis. Séchage par contact avec agitation de boues résiduaires urbaines: Influence de leur origine et des conditions opératoires sur la cinétique de séchage et les caractéristiques des boues sèches et des rejets gazeux. Université de Perpignan, Perpignan, France, pp. 182.

Chen, G., Yue, P. L. and Mujumdar, A. S. (2002). Sludge Dewatering and Drying. Drying Technology, 20(4-5): 883-916.

Christiansen, K., (1991), Possibilities and limitations to life cycle assessment, "Packaging and environment- policies, strategies and instruments", International expert seminar, (Trolleholm Castle, Sweden).

d'Arcimoles, M., (2002), Des filières d'épandage de boues urbaines déstabilisées: quelles démarches de restauration de la confiance?, Rencontre Technique Nationale: Quelles 
évolutions technologiques pour mieux garantire et pérenniser une gestion optimale des boues?, (Toulouse, France), 217-227.

de Leeuw, F. A. A. M. (1993). Assessment of the atmospheric hazards and risks of new chemicals. Procedures to estimate 'hazard potentials'. Chemosphere L2 http://dx.doi.org/10.1016/0045-6535(93)90226-U, 27(8): 1313.

Degremont,1989, Mémento technique de l'eau, Editor (eds), (Tec \& Doc-Lavoisier, Paris), pp. 592.

Gasafi, E., Meyer, L. and Schebek, L. (2004). Using life-cycle assessment in process design: Supercritical water gasification of organic feedstocks. Journal of Industrial Ecology, 7(34): 75-91.

Hall, D. O. and Scrase, J. I. (1998). Will biomass be the environmentally friendly fuel of the future? Biomass and Bioenergy, 15(4-5): 357-367.

Heijungs, H. G., J.; Huppes, G.; Lankreijer, R.; Udo de Haes, H.; Wegener, A.; Ansems, A.; Van Duin, R.; De Goede, H.P., (1992), Environmental life cycle assessment of products, Guidelines and backgrounds, Center of Environmental Sciences, University of Leiden, (Leiden, Sweden).

Hertwich, E. G., Pease, W. S. and Koshland, C. P. (1997). Evaluating the environmental impact of products and production processes: a comparison of six methods. Science of The Total Environment, 196(1): 13-29.

Hoffmann, V. H., Hungerbuhler, K. and McRae, G. J. (2001). Multi-objective screening and evaluation of chemical process technologies. Industrial and Engineering Chemistry Research, 40(21): 4513-4524.

IPCC, I. P. o. C. C., (1996), Climate change 1995: The science of climate change, Cambridge University, (Cambridge, U.K.).

Lassus, C., (1999), Campagnes de mesures realisées sur des séchoirs de boues urbaines et industrielles, Agence de l'eau Seine-Normandie, (Paris, France). 
Lassus, C. and Toupart, F., (1998), Etat de l'art sur le séchage thermique de boues urbaines et industrielles, Agence de l'eau Seine-Normandie (Paris, France).

Lowe, P. (1995). Developments in the thermal drying of sewage sludge. J. Chart. Inst. Water Environ. Manage., 9(3): 306.

Ma, F. and Hanna, M. A. (1999). Biodiesel production: A review. Bioresource Technology, 70(1): $1-15$.

McKay, G. (2002). Dioxin characterization, formation and minimization during municipal solid waste (MSW) incineration: review. Chemical Engineering Journal, 86(3): 343-368.

Miettinen, P. and Hamalainen, R. P. (1997). How to benefit from decision analysis in environmental life cycle assessment (LCA). European Journal of Operational Research, 102(2): 279-294.

Peregrina, C., Arlabosse, P. and Lecomte, D., (2004), Thermal efficiency in sewage sludge fry drying, 14th International Drying Symposium - IDS 2004, (São Paulo, Brazil), 972-978.

Pires da Silva, Peregrina, C., Arlabosse, P., Lecomte, D., Pereira-Taranto, O. and Rudolph, V., (2003), Fry-drying of sewage sludge: preliminary results, 6th Conference on Process Integration, Modeling and Optimization for Energy Saving and Pollution ReductionPRES'03, (Hamilton, Ontario, Canada),

Poulsen, T. G. and Hansen, J. A. (2003). Strategic environmental assessment of alternative sewage sludge management scenarios. Waste Management and Research, 21(1): 19-28.

Salvador, S., Kara, Y. and Commandre, J.-M. (2004). Reduction of NO emissions from a VOC recuperative incinerator by dilution of the fuel supply. Appl. Therm. Eng., 24(2-3): 245254.

Stier, R. F. (1996). Understanding High-Volume Frying. Part 1. Backing \& Snack, 70-76.

Werther, J. and Ogada, T. (1999). Sewage sludge combustion. Prog. Energy Combust. Sci., 25(1): $55-116$. 